\title{
Non-Timber Forest Products (NTFPs) and Livelihood Security: An Economic Study of High Hill Temperate Zone Households of Himachal Pradesh
}

\author{
Komal Sharma*, Ravinder Sharma and Nisha Devi
}

Department of Social Sciences, Dr. Y.S Parmar University of Horticulture and Forestry, Nauni Solan-173230 (H.P) India

*Corresponding author: kittu1992gautam@gmail.com

\begin{abstract}
Non Timber Forest Products (NTFP) can fulfill important community needs and improve rural livelihood in Parvati Forest Division of Kullu circle. There is a growing understanding about NTFPs but its importance has not been fully introduced within government frameworks and rural development policies and programs. The average family size of examined area comprised of 6 persons, out of whom 53 percent were males and rest were females. Literacy situation revealed that nearly 83.48 percent family members were literate at overall level with a literacy index of 1.84 , indicating poor quality of education in the study area. About 48.48 percent of the total land holding was cultivated area with cropping intensity 172 percent. NTFPs' contributed about 24.99 percent to the total farm income. Moreover, inclusion of NTFPs' income in the farm income resulted in reducing the income inequalities as Gini coefficient with NTFPs income from 0.20 to 0.18 . NTFPs collection generated on an average 72 days of employment to sampled households. Literacy index and land holding were found affecting NTFPs dependency negatively i.e., with the increase in the land holding size and literacy index, NTFPs dependency is going to decrease whereas, age of the household head was found positively related to the NTFPs dependency, since they had more knowledge about NTFPs uses and their method of extraction.
\end{abstract}

\section{Highlights}

0 Non Timber Forest Products (NTFPs) helps to contribute around 25\% in the income of rural farmers and NTFPs collection generated on an average 72 days of employment.

Keywords: NTFP, literacy, livelihood, land holdings, income, dependency

Non-timber forest products (NTFPs) are any product or service other than timber that is produced in forests. Non-timber forest products (NTFPs) are non-wood, minor, alternative and secondary forest products, useful substances /materials and/ or commodities obtained from forests which do not require harvesting (logging) trees. The United Nations Food and Agriculture Organization (FAO) define non-timber forest products as: "products of biological origin other than wood derived from forests, other wooded land and trees outside forests. They may be gathered from the wild, or produced in forest plantation and from trees outside forests." NTFPs embody all biological matter of wild plants and animals other than timber extracted from forests and woodlands, e.g. fruits, nuts, vegetable, medicinal plants, resins, bark, fibres, palms, grasses as well as small wood products and firewood, amongst others.

There is growing evidence that non-timber-forestproducts (NTFPs) contribute significantly to maintain livelihoods in rural area (Sarmah and Arunachalam). Livelihood refers to the "means of securing the basic necessities -food, water, shelter and clothing for life". Thus, livelihood is a set of activities, involving securing water, food, fodder, medicine, shelter, clothing and the capacity to acquire above necessities working either individually or as a group by using endowments (both human 
and material) for meeting the requirements of the self and his/her household on a sustainable basis with dignity. NTFPs help to fulfill households' subsistence and consumption needs in terms of energy and nutrition as well as medical and construction purposes (Ajaz-ul-Islam et al.).

In India over 50 million people are dependent on NTFPs for their subsistence and cash income (Hegde et al. 1996). This provides 50 per cent of household income for 20 to 30 per cent of rural population particularly for tribals. Potentially around 3000 species of forest products are found to be useful, but only 126 have developed marketability (Maithani 1994). Around 50 per cent of forest revenues and 70 per cent of forest based export income of the country comes from NTFPs. Thus, it can be depicted that NTFPs form one of the mainstays of income and sustenance for many tribal communities (Gauraha, 1992; Chopra, 1993; Mallik, 2000). An estimated 80 per cent of the population of the developing world uses Non-Wood Forest Products (NWFP) to meet some of their health and nutritional needs (FAO, 2008). It is an important source of income for the poor in many developing countries. In addition, several opportunities for improved rural development are linked to NTFPs (Adepoju, 2007).

Throughout the tropics hundreds of millions of people drive a significant part of their livelihood from a vast range of non-timber forest products that they harvest from forest (Bhavannarayana et al.). Although NTFP use by rural households is widespread, the extent of use, the quantities used and the value derived vary spatially and temporally. Understanding the significance of NTFPs in rural livelihoods is key for any development policy to respond to the needs of local people. The potential economic value of NTFPs either in terms of utilization or their market value is often underestimated or unknown. The challenge is therefore, to assess and quantify the value of these products and to transform the use of many of them as are socially and ecologically viable for subsistence and development (Sharif et al.). Hence, there is need to establish site-specific NTFP- livelihood linkages and to investigate the problems and potential of using NTFPs to sustain and improve livelihoods, and on this basis to conceptualize initiatives for supporting sustainability and higher incomes for local people in the long term. Therefore, the study was undertaken with the following specific objectives:

1. To estimate the contribution of NTFPs to household income and employment.

2. To study the socio economic factors affecting the dependency of rural household on NTFPs.

\section{MATERIALS AND METHODS}

Present study was conducted in the High Hill Temperate Wet Zone of Himachal Pradesh. Parvati forest division of Kullu circle was selected purposively. This forest division has four ranges out of which Hurla and Kasol ranges were selected. Two blocks each i.e., Garsa and Thela from Hurla range and Pulga and Tosh from Kasol range were selected. Further from the selected blocks one village each i.e., Garsa, Thela, Pulga and Barsheni were selected respectively. Fifteen households were selected from the each village.

A Simple random sampling design was used for the selection of the respondents. A sample of 60 household was taken from Parvati Forest Division of Kullu Circle of Himachal Pradesh.

\section{Sources of data}

Primary as well as Secondary data were collected for the study. The primary data were collected with the aid of structured and comprehensive schedule exclusively prepared for the study. The data collected included information on NTFPs collected and their quantities, together with demographic information of the collectors. The data were collected through a personal interview method from the selected households and traders in the study area during the year 2014-15.

Secondary data were collected from the records of the Forest Department from Kullu Circle for a period of ten years (2004-05 to 2013-14). The secondary data on quantity supplied, prices and export permit fee levied by the forest department on medicinal plants were selected.

\section{Selection of NTFP collectors}

The households of study area are geographically scattered thus, data collection was done from households who were conveniently available to participate in study. 


\section{Analytical framework}

To fulfill the specific objectives of the study and based on the nature and extent of availability of data, analytical tools and techniques have been employed for the analysis of the data. Simple tabular analysis was used to examine socioeconomic status, their resource structure, income pattern and opinions about the collection and marketing problems of NTFPs. Tabular presentation was adopted to compile the general characteristics of the sampled farmers. Simple statistical tools like averages and percentages were used to compare, contrast and interpret the results. The sex ratio, literacy rate and index were calculated.

\section{To estimate the contribution of NTFPs to household income and employment}

The objective is aimed to study scenario of NTFPs in the area. Share of NTFPs income in the total income and employment pattern was analyzed. Contribution of NTFPs collection in employment generation and pattern was studied. Gini concentration ratio helped to study the role of NTFPs in household income inequality. Gini concentration ratio is calculated by the formula:

$$
G=\frac{N+1}{N-1}-\frac{2}{N(N-1) \mu} \times \sum_{i=1}^{n} P_{i x i}
$$

Where;

$$
\begin{aligned}
& G=\text { Gini coefficient } \\
& \mu=\text { Population's mean income } \\
& P i=\text { Income rank P of person i with income X } \\
& N=\text { Rank of person with lowest income }
\end{aligned}
$$

\section{To study the socio economic factors affecting the dependency of rural household on NTFPs}

The objective is aimed to which socio-economic variable influences NTFPs dependency. Linear regression model was used to measure as the share of income from NTFPs in the total household income. In order to test which socio-economic variables influence NTFPs dependency, linear regression analysis was carried by the formula

$$
Y=a+b_{1} x_{1}+b_{2} x_{2}+b_{3} x_{3}+b_{4} x_{4}+b_{5} x_{5}+\mu
$$

Where;

$$
Y=\text { Share of NTFPs in total household income }
$$

$x_{1}=$ Farm size

$x_{2}=$ Family size

$x_{3}=$ Literacy index of the household

$x_{4}=$ Farm income

$x_{5}=$ Age of household

\section{RESULTS AND DISCUSSION}

\section{Socio-economic characteristics of sampled households}

To have a comprehensive profile of the farm households, a demographic base becomes more relevant. The social characteristics such as family size, age, work force and sex composition of farm households, dependency ratio and literacy affect the economic conditions and in turn affect social conditions. The significance of the social and demographic variables is discussed below. First, the farmers are classified in to two categories (marginal and small) on the basis of land holding.

\section{Size and structure of family}

The size and structure, work force and literacy status among the sampled households are the important factors influencing the collection of NTFPs in this area (Parvati forest division, Kullu), which happens to be family labour based occupation at the village level.

Table 1: Educational status of sampled households in the study area

\begin{tabular}{cccc}
\hline \multirow{2}{*}{ Particulars } & \multicolumn{3}{c}{ Farm Size } \\
\cline { 2 - 4 } & Marginal & Small & Overall \\
\hline Illiterate & $0.71(13.10)$ & $0.63(10.84)$ & $0.68(12.23)$ \\
Primary & $1.34(24.72)$ & $1.5(25.82)$ & $1.4(25.17)$ \\
Middle & $1.5(27.70)$ & $1.54(26.51)$ & $1.57(27.15)$ \\
Secondary & $1.15(21.22)$ & $1.4(24.10)$ & $1.25(22.48)$ \\
High & $0.21(3.88)$ & $0.22(3.80)$ & $0.21(3.77)$ \\
secondary & & & \\
Non-school & $0.5(9.23)$ & $0.5(8.60)$ & $0.5(8.99)$ \\
going & & & \\
Total & $5.42(100.00)$ & $5.81(100.00)$ & $5.56(100.00)$ \\
\hline
\end{tabular}

Figures in parentheses indicate percentage to total.

The perusal shows that at overall level the average family size was 6 members per household, 5 members per household in case of marginal farmers and 6 members per household in small farmers. 
CD Sharma et al.

Family size did not vary significantly across farm size and between regions. Likewise, the average age of household heads was above 40 years and did not vary significantly across regions. Almost all the households in the sample were male-headed. In the study area the percentage of males was 53 percent and females were 47 percent. The number of females per thousand of males ranged between 839 in case of marginal farm category to 939 in small farms with an average of 889 at the overall level. Number of nuclear families was higher 40 than the joint families 20 .

\section{Literacy status}

The overall literacy rate varied from 82.35 percent to 84.61 percent in marginal and small farm categories respectively. Male literacy rate was higher (85.91 percent) as compare to the female literacy rate (80.77 percent). The table 2 showed a marked improvement in the literacy rate. However, literacy index varied from 1.80 to 1.88 among the different categories of the farms with an overall index of 1.84. This highlighted the fact that literacy rate was higher however; the quality of education was poor as indicated by low literacy index.

Table 2: Literacy index of Sample household in the study area

\begin{tabular}{cccc}
\hline Literacy rate (\%) & Marginal & Small & Overall \\
\hline Male literacy rate (\%) & 85.15 & 86.67 & 85.91 \\
Female literacy rate (\%) & 79.07 & 82.46 & 80.77 \\
Literacy index & 1.8 & 1.88 & 1.84 \\
\hline
\end{tabular}

Source: Researcher primary data observation.

\section{Occupational distribution}

Per household occupational structure of the selected households is given in Table 3. Occupational distribution showed that in selected villages of Parvati forest division around 88.58 percent of the population was engaged in agriculture which was major constituents of livelihood occupation whereas, 7.41 percent households were engaged in business as secondary occupation at overall level followed by services (4.01 percent) in private/public sectors. Similar trends in occupational distribution were observed on small and marginal farm categories. In case of marginal farms workers engaged in service were 3.54 percent and in business were as 8.85 percent. More members of the small farm category were engaged in business (5.97 percent) than in services (4.48 percent).

Table 3: Occupational distribution of the sampled households in the study area (in percent)

\begin{tabular}{cccc}
\hline \multirow{2}{*}{ Particulars } & \multicolumn{3}{c}{ Farm Size } \\
\cline { 2 - 4 } & Marginal & Small & Overall \\
\hline Service & 3.54 & 4.48 & 4.01 \\
Business & 8.85 & 5.97 & 7.41 \\
Agriculture & 87.61 & 89.55 & 88.58 \\
\hline
\end{tabular}

Source: Researcher primary data observation.

Table 4: Farm category wise distribution of workers and dependents of the sampled Households

\begin{tabular}{cccc}
\hline \multirow{2}{*}{ Particulars } & \multicolumn{3}{c}{ Farm size } \\
\cline { 2 - 4 } & Marginal & Small & Overall \\
\hline Average no. of workers & 3.23 & 3.27 & 3.24 \\
& $(59.70)$ & $(56.25)$ & $(58.27)$ \\
Average no. of dependents & 2.18 & 2.54 & 2.31 \\
$(<14$ yrs \& $>65$ yrs $)$ & $(40.29)$ & $(43.64)$ & $(41.54)$ \\
Average family size (No.) & 5.42 & 5.82 & 5.56 \\
Dependency ratio w.r.t. total & $(100.00)$ & $(100.00)$ & $(100.00)$ \\
workers & $1: 1.47$ & $1: 1.29$ & $1: 1.40$ \\
Dependency ratio w.r.t. & & & \\
Family size & $1: 2.5$ & $1: 2.3$ & $1: 2.40$ \\
\hline
\end{tabular}

Source: Researcher primary data observation.

\section{Workforce}

The proportion of active workers was worked out to be 59.70 percent in marginal farmers and 56.25 percent in small farm categories. It was assumed that persons in the age group of 15-60 year are actively engaged in useful economic activities and were termed as working force. The dependents were found 43.64 percent in case of small farmers and 40.29 percent in the marginal farmers. The overall dependency ratio with respect to total workers was found to be 1:1.40 and among the different categories, it was observed 1:1.29 in small farms and 1:1.47 in marginal farms. Dependency ratio indicates that on an average one worker has to support more than one member in the family in the sampled area. Dependency ratio estimated with respect to family size was found 1:2.40 on an average.

\section{Distribution of sampled households according to farm size}

According to size of land holding the farmers were 
categorized in the two categories; marginal and small farmers. Most of the farmers in the studied area were having marginal and small land holdings. In case of marginal farmers the minimum size of land holding was 0.16 ha, whereas maximum was 0.8 ha. In case of small farmers minimum land holding was 1.04 ha and maximum was 1.6 ha. The data presented in Table 5, showed higher variations in land holding in marginal farmers (46.79 percent) compared to small farmers (16.70 percent) with overall variation of 63 percent.

Table 5: Distribution of sampled households according to the size of land holding

\begin{tabular}{ccccc}
\hline \multicolumn{5}{c}{ Farm size (ha) } \\
\hline Particulars & Minimum & Maximum & Average & CV(\%) \\
\hline Marginal & 0.16 & 0.8 & 0.38 & 46.79 \\
Small & 1.04 & 1.6 & 1.13 & 16.7 \\
Overall & 0.16 & 1.6 & 0.65 & 63 \\
\hline
\end{tabular}

Source: Researcher primary data observation.

\section{Income and employment structure of sampled households}

\section{Income structure}

In order to calculate income structure, share of NTFPs income in the total income and employment pattern, only those households was selected who were actively engaged in NTFPs collection. Total number of those households was 39 out of which 24 were marginal and 15 were small farmers. The present study revealed that a good number of villagers have knowledge of exploring NTFPs as about 24.99 percent of the gross income was generated from the collection of NTFPs on the overall while fruit, cereal and vegetable contributed
27.49 percent, 14.76 percent and 14.25 percent respectively (Table 6). In case of marginal farms NTFPs contributed maximum share (28.86 percent) followed by fruit (25.26 percent), whereas on small farms maximum share was from fruit (29.87 percent) followed by NTFPs (20.87 percent). Vegetables contribution varied from 11.72 percent to 16.94 percent on marginal and small farms. Thus the study revealed that the majority of households from marginal farms preferred to collect the NTFPs from the forest area as NTFPs contributed maximum proportion in their household income.

\section{Scenario of NTFPs in the study area}

NTFPs were collected all year round. However, all of them were seasonal in nature. Kutki, Dhoop, Patish and Sugandhbala were collected in the same season i.e., during July-September. The collection of Guchhi was done from January to March while Akhnor was collected during November-December. Each collector either used to make on an average of 2 to 3 visits to the forest in a month or stayed for 1520 or 30 days in a group of 5-10 persons. However, this frequency varied according to season and type of NTFPs collected. In the study area collection of NTFPs was carried out only by men, though women were engaged in household and farm activities only.

\section{Composition of NTFP employment pattern}

The collection of NTFPs generated employment to rural households. On an average 72 man days were generated in the study area. The employment generated per households per year varied between about 70 to 73 man days on small and marginal farms (Table 7). Dhoop was the major employment source contributing 28.10 percent (21mandays/

Table 6: Source of income of sample households (days/HH/year)

\begin{tabular}{ccccccccccc}
\hline \multirow{2}{*}{ Particulars } & \multicolumn{4}{c}{ Marginal } & \multicolumn{2}{c}{ Small } & \multicolumn{2}{c}{ Overall } \\
\cline { 2 - 9 } & Mini. & Max. & Average & CV (\%) & Mini. & Maxi. & Average & CV (\%) & Average & CV (\%) \\
\hline Vegetables & 5000 & 31150 & $15454(11.72)$ & 41.95 & 18125 & 73875 & $33602(16.94)$ & 44.93 & $22434(14.25)$ & 61.35 \\
Cereal crops & 7950 & 42100 & $16864(12.79)$ & 55.95 & 15900 & 49900 & $33437(16.86)$ & 32.28 & $23238(14.76)$ & 55.02 \\
Fruits & 0 & 70500 & $33292(25.26)$ & 48.33 & 27500 & 101000 & $59233(29.87)$ & 42.34 & $43269(27.49)$ & 54.29 \\
Livestock & 0 & 44800 & $28125(21.34)$ & 26.09 & 28000 & 44800 & $30613(15.44)$ & 15.25 & $29082(18.48)$ & 22.31 \\
Farm & 55450 & 146219 & $93735(71.13)$ & 25.23 & 94800 & 222863 & $156885(79.12)$ & 21.8 & $118023(75.00)$ & 35.32 \\
NTFP & 12400 & 93450 & $38038(28.86)$ & 52.87 & 13150 & 79800 & $41383(20.870$ & 57.72 & $39324(24.99)$ & 54.4 \\
Farm+NTFP & 85794 & 227088 & $131773(100.00)$ & 25.52 & 107950 & 251500 & $198268(100.00)$ & 20.68 & $157348(100.00)$ & 30.99 \\
\hline
\end{tabular}

Figures in Parentheses indicate percentage to total. 
C) Sharma et al.

$\mathrm{HH}$ /annum) to the total NTFPs employment. The collection of Dhoop was time consuming process due to the deep root system of the plant. Kutki collection was the next important employment generating activity providing employment of 14 mandays/ $\mathrm{HH}$ /annum followed by Guchhi (13 mandays/ $\mathrm{HH} /$ annum). The collection of Sugandhbala, Patish and Akhnor were contributing 14.64 percent (11 mandays/HH/annum), 14.07 percent (10 mandays/ $\mathrm{HH} /$ annum) and 6.67 percent (5 mandays/HH/ annum) respectively to the total NTFPs employment. The collection of Akhnor was generating less than 5 mandays of employment because of its easy availability and ease in its collection.

Table 7: Contribution of NTFPs collection in employment generation (Mandays)

\begin{tabular}{cccc}
\hline \multirow{2}{*}{$\begin{array}{c}\text { Name of } \\
\text { Species }\end{array}$} & $\begin{array}{c}\text { Marginal } \\
\text { Employment } \\
\text { generated } \\
\text { (days/HH/ } \\
\text { year) }\end{array}$ & $\begin{array}{c}\text { Employment } \\
\text { generated } \\
\text { (days/HH/ } \\
\text { year) }\end{array}$ & $\begin{array}{c}\text { Overall } \\
\text { Employment } \\
\text { generated } \\
\text { (days/HH/ } \\
\text { year) }\end{array}$ \\
\hline Picrorhiza & 13.28 & 14.31 & 13.66 \\
kurroa & $(17.97)$ & $(20.16)$ & $(18.76)$ \\
Jurinea & 21 & 19.54 & 20.46 \\
macrocephala & $(28.42)$ & $(27.53)$ & $(28.10)$ \\
Morchella & 12.63 & 13.4 & 12.91 \\
esculenta & $(17.09)$ & $(18.88)$ & $(17.73)$ \\
Aconitum & 10.92 & 9.09 & 10.25 \\
heterophyllum & $(14.78)$ & $(12.80)$ & $(14.07)$ \\
Valeriana & 11.31 & 9.54 & 10.66 \\
jatamansi & $(15.31)$ & $(13.44)$ & $(14.64)$ \\
& 4.73 & 5.09 & 4.86 \\
Aesculus indica & $(6.40)$ & $(7.17)$ & $(6.67)$ \\
\hline & 73.87 & 70.97 & $\mathbf{7 2 . 8 1}$ \\
Total & $\mathbf{( 1 0 0 . 0 0 )}$ & $\mathbf{( 1 0 0 . 0 0 )}$ & $\mathbf{( 1 0 0 . 0 0 )}$ \\
\hline
\end{tabular}

Figures in Parentheses indicate percentage to total.

\section{Variability in income from selected medicinal plants}

Non-timber forest products were the next major alternative source of income after agriculture in the study area because of the availability of large scale forest area. It is clear from Table 8 that on an average income generated from NTFPs was ₹ 38038, ₹ 41383 and $₹ 39234$ contributing 28.89 percent, 20.87 percent and 24.99 percent on marginal, small and on overall farmers, respectively. NTFPs played a critical role in providing subsistence and cash income to the households of the study area. The share of Kutki was maximum (65.85 percent) followed by Patish (12.93 percent) on the overall category. Similar results were found in case of marginal and small farms. The minimum share (1.14 percent) was contributed by Sugandhbala. The income from NTFPs varied between ₹ 38038/- on marginal farms to ₹ 41383/on small farms in the study area. It was concluded that from the fore going analysis that Kutki and Patish were major contributors of NTFPs income in the study area.

Table 8: Variability in income from selected medicinal plants (₹/HH/annum)

\begin{tabular}{cccc}
\hline $\begin{array}{c}\text { Name of } \\
\text { species }\end{array}$ & Marginal & Small & Overall \\
\hline Picrorhiza & 24167 & 28667 & 25898 \\
Kurroa & $(63.53)$ & $(69.27)$ & $(65.85)$ \\
Jurinea & 4125 & 4400 & 4231 \\
macrocephala & $(10.84)$ & $(10.63)$ & $(10.75)$ \\
Morchella & 2375 & 2250 & 2327 \\
esculenta & $(6.24)$ & $(5.43)$ & $(5.91)$ \\
Aconitum & 5600 & 4267 & 5087 \\
heterophyllum & $(14.72)$ & $(10.31)$ & $(12.93)$ \\
Valeriana & 437 & 473 & 450 \\
jatamansi & $(1.14)$ & $(1.14)$ & $(1.14)$ \\
Aesculus indica & 1334 & 1326 & 1330 \\
\hline Total & $(3.50)$ & $(3.20)$ & $(3.38)$ \\
\hline
\end{tabular}

Figures in parentheses indicate percentage to total.

\section{Gini concentration ratio}

To study the role of NTFPs in household income inequality Gini coefficients were estimated and results have been presented in Table 9.

Table 9: Comparison of Gini coefficient of total household income without and without NTFPs income

\begin{tabular}{cccc}
\hline Particulars & Marginal & Small & Overall \\
\hline Farm & 0.14 & 0.13 & 0.20 \\
NTFP & 0.28 & 0.33 & 0.17 \\
Farm + NTFP & 0.13 & 0.12 & 0.18 \\
\hline
\end{tabular}

The inclusion of NTFPs income in total household income considerably reduced inequality between households from 0.20 to 0.18 . In case of marginal farms Gini coefficient for farm income without 
NTFPs (0.14) reduced to 0.13 with the inclusion of NTFPs. In small farm category it has decreased to 0.12 from 0.13 . Thus, from this study it was proved that the NTFPs helped in diminishing income disparities between rural people.

\section{Cost of collection and net return from NTFP's collection}

These species were collected from the forest area and their cost of collection (qtl basis) and net return estimated were shown in Table 10. On this basis gross return and net return were calculated for all the selected species except Guchhi. In case of Guchhi because of its less availability, its cost and returns were estimated on per $\mathrm{kg}$ basis.

Table 10: Cost and Returns from NTFPs of Collection

\begin{tabular}{ccccc}
\hline $\begin{array}{c}\text { Name of } \\
\text { species }\end{array}$ & Units & $\begin{array}{c}\text { Gross } \\
\text { return }\end{array}$ & $\begin{array}{c}\text { Cost of } \\
\text { collection }\end{array}$ & $\begin{array}{c}\text { Net } \\
\text { return }\end{array}$ \\
\hline Kutki & ₹/qtls & 200000 & 7260.50 & 192739.50 \\
Dhoop & ₹/qtls & 20000 & 8693.83 & 11306.17 \\
Guchhi & ₹/Kg & 15000 & 6475.92 & 8524.08 \\
Patish & ₹/qtls & 320000 & 7493.83 & 312506.17 \\
Sugandhwala & ₹/qtls & 5000 & 4493.83 & 506.17 \\
Akhnor & ₹/qtls & 1000 & 657.50 & 342.50 \\
\hline
\end{tabular}

\section{Net return from collection of NTFPs}

The gross return cost of collection and net return from different species. Gross returns from Kutki were ₹ 200000/qtl and cost of collection was ₹ 7260.50/qtl. Therefore net returns obtained from Kutki were ₹ 192739.50/qtl. Net returns from Dhoop, Patish, Sugandhbala and Akhnor were ₹ 11306.17/qtl, ₹ 312506.17/qtl, ₹ 506.17/qtl, ₹ 342.50/qtl, respectively.
Gross returns from Guch hi were ₹ 15000/kg whereas cost of collection was ₹ 4493.83/ kg and net returns received by collection of Guchhi were ₹ $8524.08 / \mathrm{kg}$. The study revealed that the farmers were getting a good amount of net returns from the NTFPs collection.

\section{Supply analysis of selected Medicinal plants}

\section{Growth and variability in the prices}

The price analysis for the selected medicinal plants was carried out by considering their nominal and real prices. The results showed that average current prices for the selected medicinal plants were found higher as compare to average real prices. It can be seen from the table that the real prices showed a decrease of 39.77 per cent to 31.12 per cent.

Linear growth rate of nominal and real prices of selected medicinal plants showed that nominal prices of all the medicinal plants showed positive and significant growth where as in case of real prices only Dhoop showed significant growth indicating that in real term prices of Dhoop were increasing. Whereas, Guchhi and Patish were recorded with negative and significant growth rate. In nominal prices highest growth rate $(17.15 \%)$ was observed in Dhoop followed by Kutki (9.05\%), Sugandhbala (8.85\%) and Akhnor (7.79\%). The lowest growth rate was observed in Patish (3.84\%) followed by Guch i (5.09\%). In real sense only Dhoop price (6.57\%) showed significant growth whereas, real prices of other M\&APs did not show significant growth.

The analysis of coefficient of variation of nominal prices showed highest variation in prices of Dhoop

Table 11: Growth and variability in nominal as well as real prices of selected medicinal plants (2004-05 to 2013-14)

\begin{tabular}{|c|c|c|c|c|c|c|c|}
\hline \multirow[b]{2}{*}{$\begin{array}{l}\text { Medicinal } \\
\text { Plants }\end{array}$} & \multicolumn{4}{|c|}{ Nominal Prices } & \multicolumn{3}{|c|}{ Real Prices } \\
\hline & Mean (₹) & $\begin{array}{l}\text { Nominal price } \\
\text { growth rate }(\%)\end{array}$ & CV (\%) & Mean (₹) & $\begin{array}{c}\text { Percentage } \\
\text { decrease over } \\
\text { nominal prices }\end{array}$ & $\begin{array}{c}\text { Real price } \\
\text { growth rate }(\%)\end{array}$ & CV $(\%)$ \\
\hline Kutki & 361.00 & $9.05^{*}(1.46)$ & 30.10 & 238.55 & 33.92 & $-1.35(0.95)$ & 9.10 \\
\hline Dhoop & 64.50 & $17.15^{*}(3.56)$ & 60.21 & 39.80 & 38.30 & $6.57^{*}(2.39)$ & 28.56 \\
\hline Guchhi & 10000.00 & $5.09^{*}(0.63)$ & 16.33 & 6820.50 & 31.80 & $-4.67^{*}(0.83)$ & 15.84 \\
\hline Sugandhbala & 50.00 & $8.85^{*}(1.43)$ & 29.44 & 33.12 & 33.76 & $-1.33(1.29)$ & 11.74 \\
\hline Akhanor & 7.70 & $7.79^{*}(0.78)$ & 24.42 & 4.64 & 39.77 & $-2.03(1.27)$ & 10.69 \\
\hline
\end{tabular}

Figures in the parenthesis are the standard errors of the linear growth rates.

*Significant at 5 per cent level of significance respectively. 
D) Sharma et al.

(60.21\%) followed by Kutki prices (30.10\%) and lowest in Patish prices (12.61\%). In real prices also highest variation was shown by Dhoop prices (28.56\%) followed by Patish prices $(19.00 \%)$ and lowest variation by Kutki prices $(9.10 \%)$. The results have also been presented in Fig. 1.

The results have been shown in the Table 11 . The own price elasticity for Guchhi, Patish and Sugandhbala were found less than one i.e. these medicinal plants were inelastic. Whereas, own price elasticity for Kutki, Dhoop and Akhnor were elastic.
Highest price elasticity was recorded in Kutki (2.10) followed by Akhanor (1.09) and Dhoop (1.07). The lowest price elasticity was recorded for Sugandhbala (0.16) followed by Patish (0.74) and Guchhi (0.92) highlighting their responsiveness to price change. As there is positive relationship between price and quantity supplied it means more quantity will be supplied higher price and vice-versa.

\section{Nominal Price elasticity}

The arc elasticity was used to estimate the elasticity

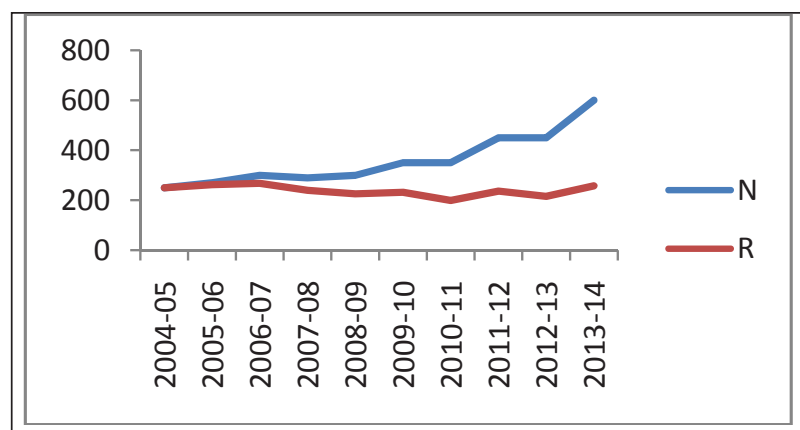

Kutki

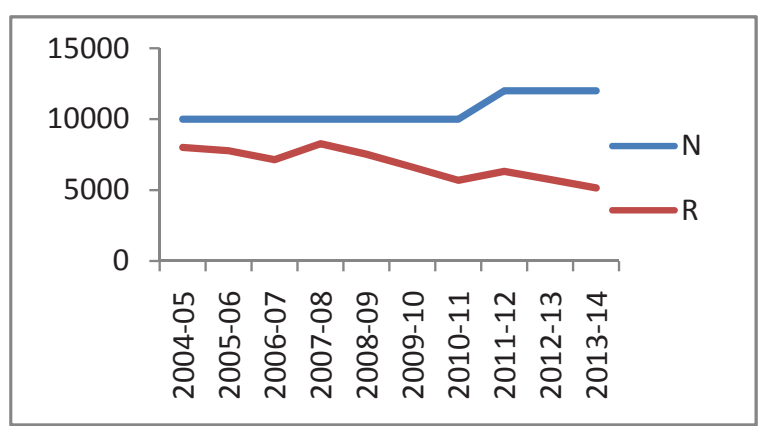

Guchhi

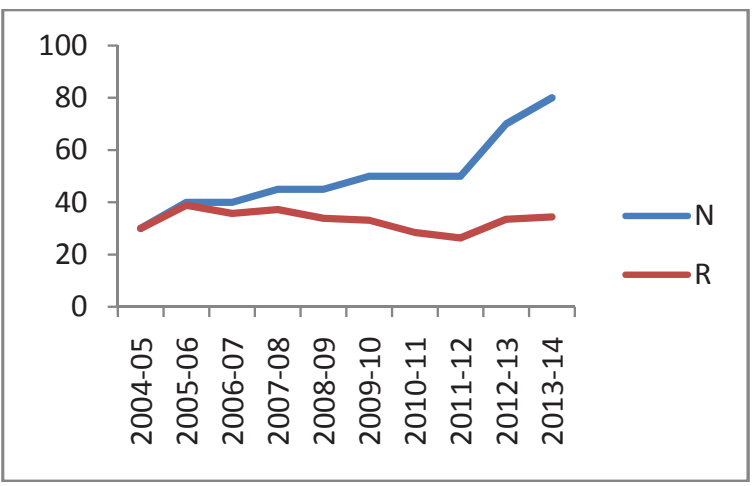

Sugandhbala

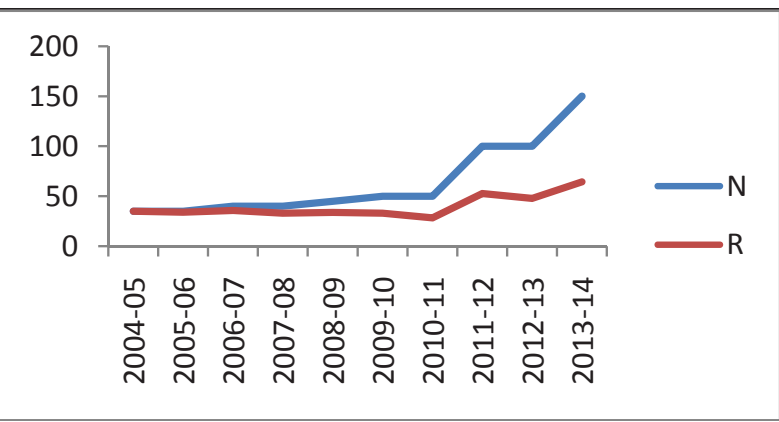

Dhoop

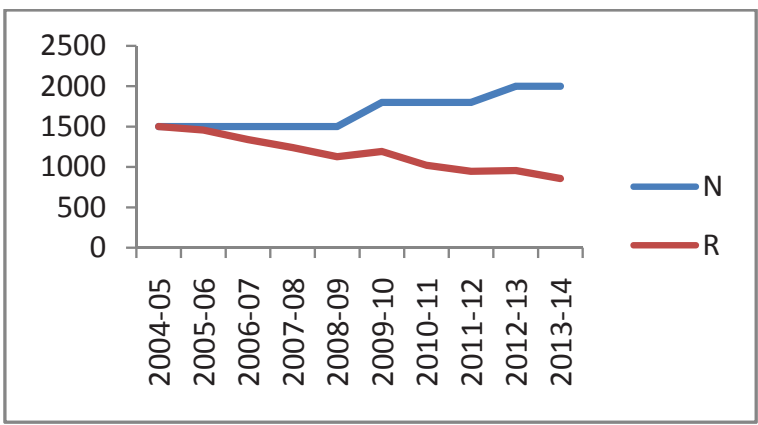

Patish

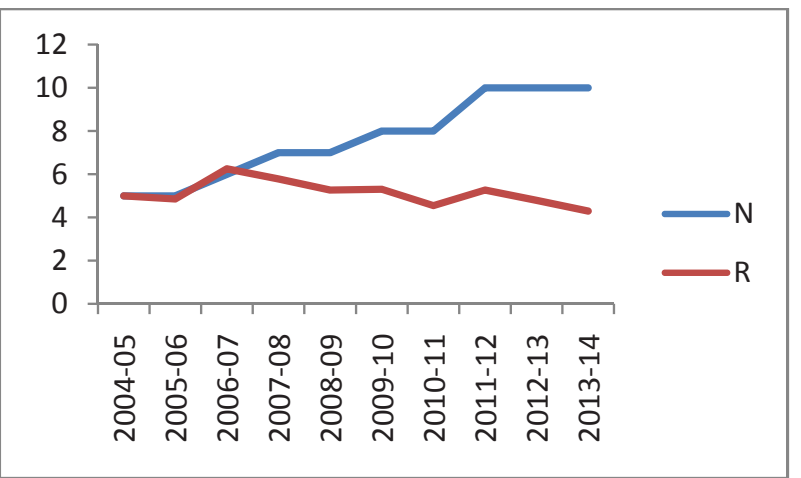

Akhanor

Fig. 1: Trends in nominal and real prices of selected medicinal plants during 2004-05 to 2013-14 
Non-Timber Forest Products (NTFPs) and Livelihood Security... $\quad \mathcal{P}$

Table 12: Nominal price elasticity of supply of selected medicinal plants during 2004-05 to 2013-14

\begin{tabular}{cccccc}
\hline Name of the species & $\begin{array}{c}\text { Average quantity in } \\
\text { the terminal years in } \\
\mathrm{qtls}\left(\mathrm{Q}_{2}\right)\end{array}$ & $\begin{array}{c}\text { Average quantity } \\
\text { in the base years in } \\
\mathrm{qtls}\left(\mathrm{Q}_{1}\right)\end{array}$ & $\begin{array}{c}\text { Average price in } \\
\text { the terminal years } \\
\left(\mathrm{P}_{2}\right)\end{array}$ & $\begin{array}{c}\text { Average price in the } \\
\text { base years }\left(\mathrm{P}_{1}\right)\end{array}$ & $\begin{array}{c}\text { Elasticity of } \\
\text { Supply }\end{array}$ \\
\hline Kutki & 270.90 & 64.66 & 500 & 273.33 & 2.10 \\
Dhoop & 125.66 & 35.66 & 116.66 & 36.66 & 1.07 \\
Guchhi & 10.51 & 7.24 & 12000 & 8000 & 0.92 \\
Patish & 1.93 & 1.6 & 1933.33 & 1500 & 0.74 \\
Sugandhbala & 7.31 & 6.66 & 66.66 & 36.66 & 0.16 \\
Akhanor & 4.36 & 2.33 & 10 & 5.66 & 1.09 \\
\hline
\end{tabular}

Table 13: Real price elasticity of supply of selected medicinal plants during 2004-05 to 2013-14

\begin{tabular}{cccccc}
\hline $\begin{array}{c}\text { Name of the } \\
\text { species }\end{array}$ & $\begin{array}{c}\text { Average quantity } \\
\text { in the terminal } \\
\text { years in qtls } \mathbf{(}_{\mathbf{2}} \mathbf{)}\end{array}$ & $\begin{array}{c}\text { Average quantity } \\
\text { in the base years in } \\
\mathbf{q t l s}\left(\mathbf{Q}_{\mathbf{1}}\right)\end{array}$ & $\begin{array}{c}\text { Average price in } \\
\text { the terminal years } \\
\mathbf{( P}_{\mathbf{2}} \mathbf{)}\end{array}$ & $\begin{array}{c}\text { Average price } \\
\text { in the base } \\
\text { years }\left(\mathbf{P}_{\mathbf{1}} \mathbf{)}\right.\end{array}$ & $\begin{array}{c}\text { Elasticity of } \\
\text { Supply }\end{array}$ \\
\hline Karoo & 270.903 & 64.66 & 236.55 & 260.00 & 13.02 \\
Dhoop & 125.667 & 35.66 & 54.95 & 34.90 & -2.50 \\
Guchhi & 10.51 & 7.24 & 5735.87 & 7636.62 & 1.30 \\
Patish & 1.93 & 1.6 & 920.89 & 1431.87 & 0.43 \\
Sugandhbala & 7.31 & 6.66 & 31.38 & 34.84 & 0.89 \\
Akhanor & 4.36 & 2.33 & 4.78 & 5.07 & 10.31 \\
\hline
\end{tabular}

Table 14: Scarcity ratios of selected medicinal plants supplied during 2004-05 to 2013-14

\begin{tabular}{ccccccc}
\hline \multirow{2}{*}{ Years } & \multicolumn{7}{c}{ Selected medicinal plants } \\
\cline { 2 - 7 } & Karoo & Dhoop & Guchhi & Patish & Sugandhbala & Akhnor \\
\cline { 2 - 7 } & \multicolumn{7}{c}{ Quantity (qtls) } \\
\hline $2004-05$ & 37 & 38 & 2.61 & 0.3 & 7 & 0.5 \\
$2005-06$ & 74 & 46 & 15.21 & 1.6 & 9 & 3 \\
$2006-07$ & 83 & 23 & 3.9 & 2.9 & 4 & 3.5 \\
$2007-08$ & 46.5 & 18 & 1.44 & 4 & 9 & 5 \\
$2008-09$ & 125.9 & 29 & 2.55 & 1.9 & 5 & 10 \\
$2009-10$ & 103 & 23 & 2.9 & 3 & 4 & 7 \\
$2010-11$ & 92.7 & 55 & 3.5 & 0.11 & 1 & 6.5 \\
$2011-12$ & 231.71 & 48 & 5.2 & 0.41 & 4.2 & 4.3 \\
$2012-13$ & 259 & 119 & 15.66 & 2.5 & 7.25 & 5 \\
$2013-14$ & 322 & 210 & 10.69 & 2.9 & 10.5 & 3.8 \\
Scarcity ratio & 1.37 & -0.45 & 56.36 & 8.20 & -0.67 & -0.95 \\
\hline
\end{tabular}

of supply of selected medicinal plants. The values were positive for all the medicinal plants showing the positive price supply elasticity relationship.

\section{Real price elasticity}

The own price elasticity was also estimated for real prices and results have been shown in the Table 14 . The price elasticity for all the medicinal plants was positive except Dhoop (-2.50) which indicated that Dhoop was very inelastic in nature, i.e., change in price does not affect the quantity supplied of the species.

\section{Scarcity ratio of selected medicinal plants}

The real increase in the price of the resources over a period of time indicates the economic scarcity of the resources (Suneeta, 1998). Kutki, Guchhi and Patish had positive ratio implying thereby that these species are highly scarce in nature. The scarcity ratio was found highest in Guchhi (56.36) followed 
D) Sharma et al.

Table 15: Regression of NTFPs incomes against socio-economic variables (estimation of NTFP income share)

\begin{tabular}{ccccc}
\hline Terms & Coefficient & SE & t-value \\
\hline Intercept & -17493.641 & 14891.213 & -1.175 \\
Land holding & -33481.166 & 7613.612 & $-4.398^{*}$ \\
Size of family & 1189.579 & 1480.649 & 0.803 \\
Literacy index & -13358.672 & 3931.005 & $-3.398^{*}$ \\
Farm income & 0.15 & 0.076 & 1.979 \\
Age of household head & 1292.199 & 255.12 & $5.065^{*}$ \\
\hline
\end{tabular}

-N=39: $R^{2}=0.722:$ Adjusted $R^{2}=0.680 ; *$ Significant at 5 per cent level of significance respectively.

by Patish (8.20) and Kutki (1.37) shown in Table 15. Hence, availability of these species is becoming scarce over the period of time. Other selected medicinal plants showed negative ratios indicating their abundant availability in nature.

\section{Socio-economic factors affecting NTFPs income share}

Land holding of sampled households, size of family, literacy index, farm income and age of household were found affecting the NTFPs income share. Out of these five variables only three variables, viz., land holding, literacy index and age of household head significantly affected the NTFPs collection. Land holding and literacy index were found affecting the NTFPs income share negatively i.e., with the increase in the land holding size and literacy index, NTFPs income share is going to decrease. The literacy index was very low in the study area (1.84) indicating that quality of education was low. Thus lower the formal education, more the income share on NTFPs.

Age of household head was found positively related to the NTFPs income share, since old households were assumed to have more knowledge about the NTFPs uses and their extraction. Moreover they were having lower formal education. Both knowledge and skills were spread within the family. Additionally, as elder people often were limited in their physical performance, they were more likely to be engaged in NTFPs extraction. Thus, higher age of household head positively affected NTFPs income share.

Other variables like size of family and farm income were also considered which were found not significantly affecting the NTFPs income. It showed that people from nuclear family and from joint family collect the species in the same proportion. Similarly, farmers with high farm income were also collecting the NTFPs for their additional income. The factors considered together were able to explain the NTFPs income share up to 68 percent. This Adjusted R-Squared value adjusts the statistics based on the number of independent variables in the model and it is a desired property of a goodness of fit statistics. There may be some other factors affecting the income share of NTFPs.

\section{CONCLUSION}

Literacy situation revealed that nearly 83.48 percent family members were literates at overall level with a literacy index of 1.84 , indicating poor quality of education in the study area. Occupational distribution revealed that 88.58 percent of work force in the sampled households practice farming, followed by business sector (7.41 percent) and service sector (4.01 percent) at overall level. On an average, 58.27 percent were the workers in family in overall farms. The proportion of workers found on marginal farms (59.70 percent) higher compared to small farms (56.25 percent). The overall dependency ratio w.r.t. total worker was worked out to be 1:1.40 and dependency ratio w.r.t. family size was 1:2.40 indicating that on an average one worker has to support more than two family members. The average size of land holding of the sampled households was found 0.66 hectares of which 48.48 percent was cultivated area. The other uses of land were pastures/ghasnis (16.18 percent), orchards (22.72 percent) and barren land (10.89 percent). The cultivated land varied from 55.26 percent to 46.01 percent in marginal to small categories of the farm. NTFPs contributed maximum in the total income in case of marginal farms (28.86 percent) whereas, in small farms NTFPs contribution was 20.87 percent. 
On an average, NTFPs contributed 24.99 percent to the total farm income in the study area. Gini coefficient value without NTFPs income was 0.20 , which reduced to 0.18 with the inclusion of NTFPs income. Literacy index and land holding were found affecting NTFPs income share negatively i.e., with the increase in the land holding size and literacy index, NTFPs income share is going to decrease whereas, age of the household head was found positively related to the NTFPs income share, since they had more knowledge about NTFPs uses and their method of extraction.

\section{REFERENCES}

Adepoju, A.A. and Salau, A.S. 2007. Economic valuation of non-timber forest products (NTFPs), Munich Personal RePEc Archive (MPRA) Paper no. 2686. http://mpra. ub.uni-muenchen.de

Ajaz-ul-Islam, M., Sulaiman Quli, S.M., Rai, R. and Sofi, P.A. 2013. Livelihood contribution of forest resources to tribal communities of Jharkhand. Indian Journal of Fundamental and Applied Life Sciences, 3(2): 131-44

Bhavannarayana, C., Saritha, V., Usha, P., and Brahmaji, Rao, P. 2012. Dependency and usage pattern of forest-dwellers on non-timber forest product. Erudite Journal of Ecology and Environmental Research, 1(1): 1-5.

Chopra, K. 1993. The Value of Non-Timber Forest Products: An estimation for tropical deciduous forests in India, Economic Botany, pp 251-257. In: International association of agricultural economists' conference. 12-18 August, 2003, Ravi et al (eds.). Gold Coast, Australia.

https://www.jstor.org/stable/4255519
Hegde, R., Suryaprakash, S., Achoth, L. and Bawa, K.S. 1996. Extraction of NTFPs in the Forests of B.R. Hills. Contribution to Rural Income. Economic Botany, 50: 243244.

Food and Agriculture Organization 2008. An information bulletin on Non Wood Forest Products. Non- Wood News. Rome, Italy.

Gauraha, A.K. 1992. Micro-economic analysis of a tribal village. Indian Journal of Agricultural Economics, 47(3): 446-447.

Maithani, G.P. 1994. Management perspectives of Minor Forest Produce. MFP News, October-December, 1994. Dehradun.

Mallik, R.H. 2000. Sustainable management of Non-Timber Forest Products in Orissa: Some issues and options. Indian Journal of Agricultural Economics, 55(3): 384-397.

Sarmah, R. and Arunachalam, A. 2011. Contribution of non-timber forest products to livelihood economy of the people living in the forest in Changlang district of Arunachal Pradesh, India. Indian Journal of Fundamental and Applied Life Science, 1(2): 157-169.

Sharif, A.M., Rashid, A., Uddin, M.B. and Khan, N.A. 2015. Role of non-timber forest products in sustaining forestbased livelihoods and rural households' resilience capacity in and around protected area: a Bangladesh study. Journal of Environmental Planning and Management, 58: 1-15.

Suneetha, M.S. 1998. Demand and valuation of medicinal produces and produces in Western Ghats of Kerala: a resource economics study. M.Sc. (Agri.) Thesis, University of Agricultural Sciences, Bangalore. 
